\title{
DETERMINANTS OF TRUST AND CUSTOMER LOYALTY ON C2C E-MARKETPLACE IN INDONESIA
}

\author{
Widarto Rachbini, Iha Haryani Hatta \\ Postgraduate School, Faculty of Economics and Business, \\ Universitas Pancasila, Indonesia \\ Tiolina Evi \\ Department Accounting, Faculty of Economics and Business \\ Perbanas Institute, Indonesia
}

\begin{abstract}
Stakeholders in C2C e-marketplace in order to optimize the category of groceries. One way to do this is through customer equity management. Therefore, it is very important to conduct research on the analysis of customer equity, customer loyalty in the context of c2c e-marketplace in Indonesia (study in the product groceries category) which aims to partially determine the effect of brand equity, value equity and relationship equity on trust and customer loyalty and the influence of trust on customer loyalty. The design of this study uses an explanatory approach. The data analysis technique uses structural equation model (SEM) and sampling is limited to certain criteria (purposive sampling). This study used 200 respondents. The results of this study show that there is a partial influence of brand equity and value equity on constructs of trust and customer loyalty. Meanwhile, relationship equity has a direct effect on trust, but not on customer loyalty. Trust affects consumer loyalty. Companies must focus on rewarding systems through cash back reward programs, virtual loyalty cards, incentive programs, and virtual communities that have been proven to be able to increase customer loyalty.
\end{abstract}

Keywords: Brand Equity, Value Equity, Relationship Equity, Trust, Customer Loyalty.

Cite this Article: Widarto Rachbini, Iha Haryani Hatta and Tiolina Evi, Determinants of Trust and Customer Loyalty on C2C E-Marketplace in Indonesia, International Journal of Management, 10 (3), 2019, pp. 119-129.

$\mathrm{http}: / /$ iaeme.com/Home/issue/IJM?Volume=10\&Issue=3

\section{INTRODUCTION}

The emergence of internet and portable devices has an impact on $\mathrm{C} 2 \mathrm{C}$ e-commerce which is experiencing rapid development throughout the world (Dan, 2014). The internet has become a part of life in everyday life that cannot be separated from modern human life since the 
commercialization of the internet in the mid-90s (Rachbini and Hatta, 2018). Currently there are three players in the $\mathrm{C} 2 \mathrm{C}$ e-marketplace category that have a balanced portion, namely BukaLapak, Shopee, Tokopedia.

This should be a concern for stakeholders in the $\mathrm{C} 2 \mathrm{C}$ e-marketplace in order to optimize the daily food sub-category which is one of the basic needs of the Indonesian people. One way is to manage customer assets more effectively through customer equity management. According to Villanueva (2003), customer equity is looking at customers as the main source of cash-flows now and in the future. Customer equity is able to have a positive impact on customer trust and customer loyalty (Ramaseshan et al., 2013). So that companies build long-term relationships with customers because the attachment leads to achieving higher profits (Kohlmeyer, 2016).

The customer equity concept combines brand management, relationship management, retention management, and customer value management (Zhang et al., 2010). "Customer equity is one of the main keys of marketing due to its ability to assess individuals, and customer segments from a perspective" (Rust et al., 2000). By creating value for consumers, companies in turn obtain value from consumers in the form of sales, profits, and customer equity in the long run (Kotler and Armstrong, 2018). "Customer equity is formed on the basis of three main dimensions, namely value equity, relationship equity, and brand equity" (Lemon et al., 2001). To maximize the long-term performance of a company, a marketing manager needs to make more responsible marketing investments by continuing to monitor these three things (Ramaseshan et al., 2013).

Today more and more companies are shifting their focus to brand management towards customer management. While customer equity can be a better measure of company performance than current sales or market share. Companies must be able to manage customer equity well, must see customers as assets that need to be managed and maximized (Kotler and Armstrong, 2018). Vogel et al., (2008) and Johnson et al., (2006) revealed that customer equity can encourage an increase in customer loyalty. Customer loyalty involves the intention to be involved in future buying behavior with the same company or brand (Zhang et al., 2010). Customer loyalty has a positive impact on profitability for a business/company (Ramaseshan et al., 2013). Loyal customers have more long-term relationships with companies and are more profitable because they are more easily served, able to pay higher prices, and recommend products/services to new customers (Zhang et al., 2010). Meanwhile, Customer Loyalty is highly related to trusts. Ramaseshan et al., (2013) revealed that customer trust plays an important role in mediating customer equity and customer loyalty. Trust in a well-known brand allows customers to feel security and reliability (Ballester and Aleman, 2001). Romaniuk and Bogomolova, (2005) revealed that trust is considered an asset for a brand that can produce an increase in customer loyalty.

Research topics related to customer equity have been extensively investigated and several frameworks have been proposed and tested empirically (e.g. Bolton et al., 2004; Rust et al., 2004; Vogel et al., 2008; Zhang et al., 2010; Ramaseshan et al., 2013). This study aims to determine the partial effect of brand equity, value equity, and relationship equity on trust and customer loyalty, and the effect of trust on customer loyalty.

\section{LITERATURE REVIEW AND HYPOTHESES DEVELOPMENT}

\subsection{Customer Equity}

According to Keller (2013), "the main objective of customer relationship management is to produce high customer equity. Customer equity is the combination of total customer lifetime values of all current customers and potential customers in the future". The more loyal the customer is to a company and provides many benefits, the higher the customer equity (Kotler and Armstrong, 2018). "Customer equity is a combination of the value of the firm's current and 
potential customer assets"(Hogan et al., 2002). Wirtz and Lovelock (2018) define customer equity as customer lifetime values originating from a customer base in a company.

Customer equity identifies customer values and focuses on obtaining customer lifetime value (Ramaseshan et al., 2013). Blattberg et al., (2001) revealed that there are two main reasons why companies should use the customer equity approach. First, the development of new technology makes customer asset-based management something feasible. Second, these technological capabilities are accompanied by various changes in the way the market works in the midst of an unstable business environment, making marketing must be managed well to maximize the value of the customer assets of a company. Lemon et al., (2001) succeeded in identifying three key drivers of customer equity, namely value equity, brand equity, and relationship equity. The three key drivers are able to work partially or simultaneously in increasing customer equity and the value of the firm.

\subsection{Brand Equity}

Strong brands have high brand equity. This is a measure of the brand's ability to capture consumer preferences and loyalty (Kotler and Armstrong, 2018). "Brand equity is the customer's subjective assessment of the brand and is more concerned with the image of a brand" (Rust et al., 2000). "Consumers are more likely to know brands that have high reputation, image, and strengthen consumer experience" (Pae et al., 2002). If a customer feels that a brand is strong, unique, and desirable, then the customer feels high brand equity (Verhoef et al., 2007).

Brands are the best thing to build an image that makes customers able to identify a specific thing compared to other things (Ramaseshan et al., 2013). Brand equity is a subjective and intangible assessment perceived by customers of a brand (Lemon et al., 2001; Kim and Brandon, 2010). Brands must be different, and must stand out in ways that are relevant to consumer needs. Before consumers respond to brands, they must know and understand them first. This must lead to positive consumer-brand connections (Kotler and Keller, 2016). Thus, positive brand equity comes from consumers' feelings about brands and connections with brands. A brand with high brand equity is a very valuable asset (Kotler and Armstrong, 2018).

High brand equity gives the company a number of competitive advantages. Strong brands have high brand awareness and customer loyalty. In addition, however, strong brands are capable of forming customer engagement and customer relationships. The thing that underlies brand equity is customer equity which is the value of customer relationships made by a brand. A strong brand is important, but what it really represents is a group of loyal customers that provides many benefits. The right focus of marketing is to build customer equity with brand management that serves as the main marketing tool. In addition, company investment in brand equity can increase customer trust which ultimately can influence customers' price tolerance for a brand (Delgado-Ballester et al., 2003).

\subsection{Value Equity}

In general, value is the key to customer relations with the company (Zhang et al., 2010). Value equity is the objective assessment of customers about the usefulness of a brand based on perceptions of what is given and what is received (Vogel et al., 2008). This can be understood as a ratio in which things are perceived from what is received, and things that have been sacrificed. In other words, "the perceived ratio between what is received (such as different products and benefits) and what is sacrificed (such as the price paid for a product) and thus a higher benefit cost ratio will result in higher value equity" (Ramaseshan et al., 2013). Value equity refers to customer's objective evaluation for the utility factor of a product or service based on the perception of what is paid for what is received (Lemon et al., 2001). 
In addition, the three key drivers that influence value equity are quality, price, and convenience (Lemon et al., 2001). Value equity becomes important when there are significant differences with competing products (Ramaseshan et al., 2013). Investments are made on value equity, so they can create higher trusts that can change customer behavior because trust is one of the most important factors in maintaining long-term relationships (Ryssel et al., 2004).

Value is the fundamental customer relationship with the company. The best brand marketing strategy or relationship marketing will not be enough if the company's products and or services do not meet customer needs and expectations (Ramaseshan et al., 2013). Rust et al. (2004) succeeded in proving that value equity is able to increase customers' loyalty intentions. Meanwhile, Vogel et al. (2008) in his study showed a direct relationship between value equity and customer loyalty. "Value equity affects loyalty, both directly and indirectly through trust as a mediator of the relationship" (Ramaseshan et al., 2013). Molinari et al., (2008) found that "perceived value is one of the key factors in getting actual repurchase which is part of customer loyalty".

\subsection{Relationship Equity}

The tendency of customers to maintain the brand from objective and subjective judgment of the brand. The four key drivers of relationship equity are loyalty programs, special recognition and treatment programs, community building programs, and knowledge development programs (Keller, 2013). Relationship equity is the tendency of customers to stick around using a brand regardless of their subjective and objective judgment on the brand (Lemon et al., 2001).

Relationship equity focuses on switching costs that bind customers and companies, based on actions taken by companies and customers to build and create relationships. Relationship programs can be implemented in various ways. One example, when companies provide additional benefits for customers to move, reward programs and strengthen customer relationships through emotional ties. Relationship equity is very important when the benefits obtained by customers through loyalty programs are greater than the actual benefits obtained (Aravindakshan et al., 2004). In addition, trust in previous studies conducted by Ramaseshan et al., (2013) acts as full mediators for relationship equity and customer loyalty relationships.

\subsection{Trust}

Transactions in $\mathrm{C} 2 \mathrm{C}$ e-marketplaces operate platforms used to communicate and complete transactions (Wei et al., 2018). Trust plays an important role in electronic trading transactions (e-commerce) when there is a perceived high risk (Gefen et al., 2003). In a C2C environment e-marketplace, buyers and sellers do not know each other so it is difficult to develop emotional ties during the transaction (Wei et al., 2018). Trusts are often identified in interpersonal buyerssellers, namely interpersonal trust (Chang et al., 2013). Trust can be interpreted as customer confidence in certain brands that can satisfy customer desires (Rachbini, 2018).

Trust can be seen as a social construct which then develops into two dimensions, namely cognitive and affective aspects (Johnson and Grayson, 2005). "Cognitive trust is a rational view that can be explained as the willingness of the buyer to depend on the competence and reliability of the service provider company". Furthermore, affective trust is an emotional view that can be assessed as a perception of buyer actions that are intrinsically able to motivate others to remain in a relationship (Ramaseshan, 2013).

Trust is a key factor to make customers loyal (Kohlmeyer, 2016). Trusts induce repeat purchases made by customers based on evidence of a company's reliability in providing expected value over time (Sirdeshmukh et al., 2002). Previous research conducted by Singh and Sirdeshmukh, (2000) proved empirically that "there is a positive impact of trust on customer 
loyalty, and even trust is considered more important than satisfaction in forming loyal customer base" (Ranaweera and Prabhu, 2003).

\subsection{Customer Loyalty}

Today, many companies focus on customer relationship management which aims to manage customer information and customer touch points to maximize customer loyalty (Kotler and Armstrong, 2018). Customer loyalty is an attachment or deep commitment from buyers to repurchase a product, service, brand, or organization in the future, even though there are situational influences and marketing efforts that have the potential to trigger switching behavior (Oliver, 1999). Ludin and Cheng, (2014) describe customer loyalty as a continuous relationship between customers and brands. Customers can develop a strong sense of loyalty to the brand, as reflected in retention, repurchase, and finally recommending the brand (Kotler et al., 2017).

Kotler et al., (2017) also revealed that in pre-connectivity era, loyalty is often defined only as retention and repurchase. Tabaku and Zerellari, (2015) revealed that there are two approaches to customer loyalty, namely behavioral and attitudinal. The behavioral approach in customer loyalty refers to the consistency of customers and the sustainability of purchases, while the attitudinal approach is the psychological connection of customers with products or services that involve preferences and components such as positive attitudes and commitment.

Companies can learn customer loyalty by analyzing loyalty patterns in a market. This can be started from studying the company's loyal customers. Customers who have high loyalty are real assets. They can promote brands through personal word of mouth, as well as social media. A person can be loyal to brands, stores, and also companies. Buyers can be classified according to their level of loyalty (Kotler and Armstrong, 2018).

Thus, referring to the number of descriptions above related to customer equity, trust, and customer loyalty, the following are some of the hypotheses that can be formulated in this study:

$\mathrm{H}_{1} \quad$ : Brand equity has a positive effect on trust

$\mathrm{H}_{2} \quad$ : Value equity has a positive effect on trust

$\mathrm{H}_{3} \quad$ : Relationship equity has a positive effect on trust

$\mathrm{H}_{4} \quad$ : Brand equity has a positive effect on customer loyalty

$\mathrm{H}_{5} \quad$ : Value equity has a positive effect on customer loyalty

$\mathrm{H}_{6} \quad$ : Relationship equity has a positive effect on customer loyalty

$\mathrm{H}_{7} \quad$ : Trust has a positive effect on customer loyalty

\section{RESEARCH METHODOLOGY}

\subsection{Research Design}

The design of this research uses an explanatory approach. Through explanatory studies it is expected to be able to find out how the influence between two, three, or more constructs and patterns, directions, and strengths on each of these influences (Leedy and Ormrod, 2005).

\subsection{Data Collection}

The method of data collection in this study uses a non-probability sampling approach. Nonprobability sampling is more reliable than other approaches and can provide some important clues to getting potential information and relating to the population (Sekaran and Bougie, 2016). In this research, the researchers used purposive sampling as an approach to collect data in the field.

Sampling of this type is limited to certain types or individuals who can provide the desired information, either because of the one who owns it, or in accordance with the specified criteria. 
This type of sampling design is referred to as purposive sampling (Sekaran and Bougie, 2016). Thus, this study uses primary data and researchers take a number of respondents selected based on certain criteria, namely consumers who have shopped groceries in $\mathrm{C} 2 \mathrm{C}$ e-marketplace in Indonesia such as BukaLapak, Tokopedia, and Shopee which are in the top C2C e-marketplace based on the frequency of visits and ranking of applications on the Play Store (Daily Social, 2018). Hair et al., (2010), revealed that the results of statistical testing were very sensitive to the size of the sample, and according to him the ideal number of samples was at least 100-200 respondents to use structural equation modeling (SEM) as a data analysis technique to be used.

\subsection{Research Questionnaire}

The indicators used in the questionnaire in this study adopted and referred to several previous studies conducted by Verhoef et al., (2007) to measure brand equity; Vogel et al., (2008) to measure relationship equity; Sirdeshmukh et al., (2002) to measure value equity; Doney and Cannon (1997) to measure trust; and Zeithaml et al., (1996) to measure the construct of customer loyalty.

The questionnaire was distributed to 235 respondents in the DKI Jakarta province which is the capital city of Indonesia. The researchers managed to collect 200 respondents' answers that filled out the questionnaire completely and correctly, thus the response rate obtained was $85.10 \%$.

\section{RESEARCH RESULT}

\subsection{Characteristics of Respondents}

The majority of respondents in this study belong to the generation of millennial with an age range of $20-39$ years of $88.50 \%$, the remaining $11.50 \%$ were in the age range of $40-54$ years in the Gen X category (Alvara Research, 2016). Furthermore, the majority of sexes in this study were women $(81.65 \%)$, and men $(18.35 \%)$. This is certainly interesting because as stated by Kotler et al. (2017) that in many countries the role of women as housewives is like that of a chief financial officer in a family. In addition, the majority of respondents have undergraduate education (92.50\%), diploma (7.50\%) and have shopped for groceries in C2C e-marketplace in Indonesia such as BukaLapak, Tokopedia, and Shopee (100.0\%).

The independent variable of the study is brand equity (4 indicators), value equity ( 4 indicators), and relationship equity (4 indicators). The non-independent variables are trust ( 8 indicators), and customer loyalty (5 indicators). All of these variables are reliable because they have alpha Cronbach values $\geq 0,70$. All these indicators are valid because they have a factor loading of 60.6 (Hair et al., 2010).

\subsection{Evaluation of Research Models}

The results of confirmatory factor analysis test (CFA) show that the model in this study has an acceptable construct of validity and reliability, and indicates a good fit model where all indicators used to measure each variable prove valid with a factor loading greater than 0.60 . Furthermore, the good fit model can also be seen from the CFI value $=1.00, \mathrm{NNFI}=0.99, \mathrm{x}^{2}=$ 288.42 with $265 \mathrm{df}, \mathrm{x}^{2} / \mathrm{df}=1.08$, and RMSEA $=0.014$. These results also represent that the model in this study is feasible to use.

\subsection{Research Hypothesis}

Analysis through structural equation model (SEM) using LISREL shows $\mathrm{H}_{1}-\mathrm{H}_{3}$, brand equity $(\mathrm{t}=4.34, \mathrm{p}<0.05)$, value equity $(\mathrm{t}=4.84, \mathrm{p}<0.05)$, and relationship equity $(\mathrm{t}=5.44, \mathrm{p}<0.05)$ has a positive and significant effect on trust. Meanwhile, $\mathrm{H}_{4}-\mathrm{H}_{6}$, brand equity $(\mathrm{t}=3.08, \mathrm{p}<$ 
$0.05)$, value equity $(\mathrm{t}=2.14, \mathrm{p}<0.05)$, has a positive and significant effect on customer loyalty. Meanwhile, relationship equity $(\mathrm{t}=1.63, \mathrm{p}>0.05)$ has no significant effect on customer loyalty. Furthermore, $\mathrm{H}_{7}$, trust $(\mathrm{t}=3.95, \mathrm{p}<0.05)$ has a positive and significant effect on customer loyalty. Thus, it can be concluded that the customer equity dimensions of brand equity, value equity, relationship equity have a significant effect on trust, and brand equity, value equity, trust has a significant effect on customer loyalty. To find out the description related to the full structural model in this study, the following are the SEM outputs from the results of data processing, including the following:

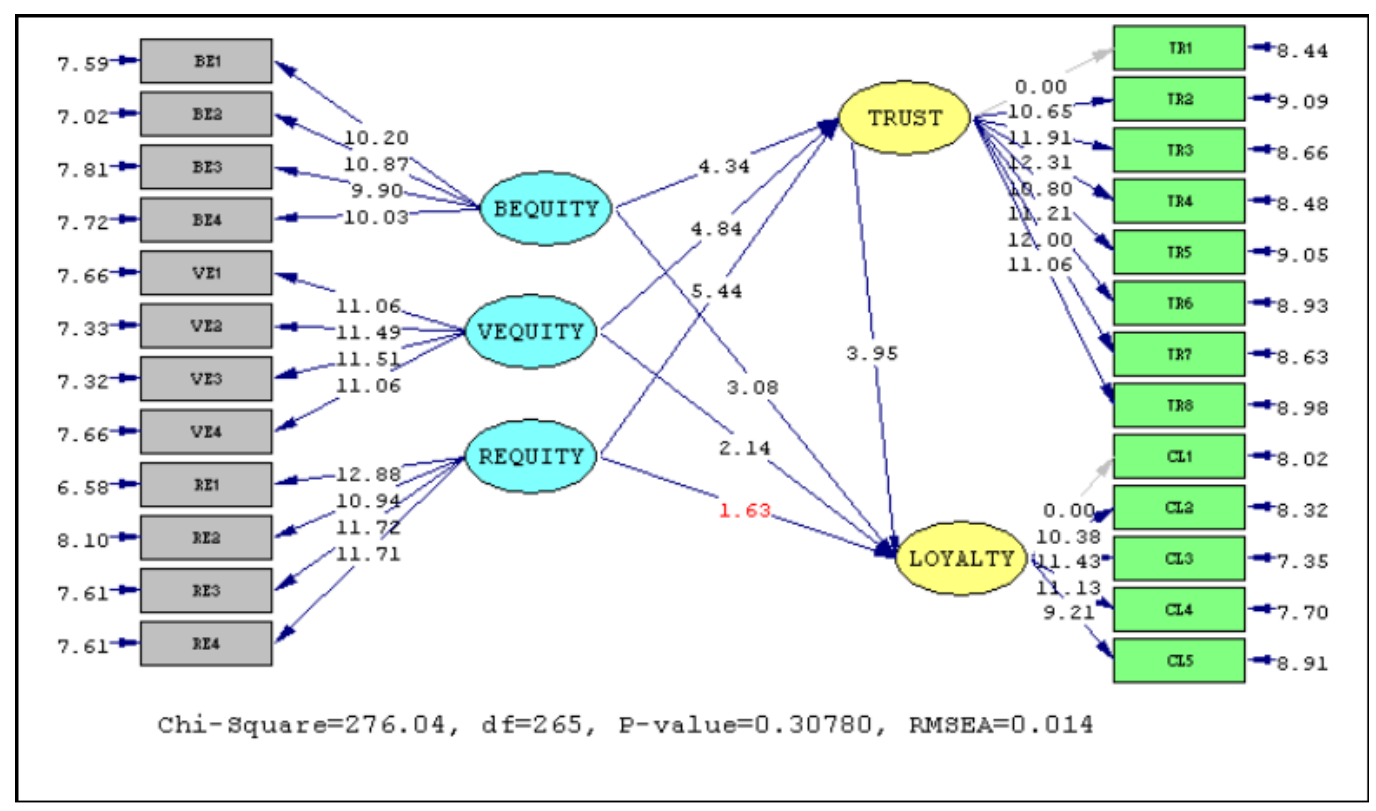

Figure 1 Research Model

The findings in this study show that customer equity dimensions of brand equity, value equity, and relationship equity have a significant effect on trust constructs. Meanwhile, brand equity, value equity, and trusts are also proven to be able to influence customer loyalty. There is only one exception where relationship equity shows insignificant results or in other words does not directly affect customer loyalty. The results of this study support the findings obtained by Ramaseshan et al. (2013) in which the study successfully proved that value equity has a significant effect on trust and customer loyalty. In the context of $\mathrm{C} 2 \mathrm{C}$ e-marketplace, buyers try to buy quality products at economical prices while sellers try to make long-term profits by selling products on a regular basis (Meehan and Wright, 2011). Value is the basic element in terms of customer relations with the company. The best brand marketing strategy or relationship marketing will not be enough if the company's products or services do not meet customer needs and expectations. Value equity comes from a profitable price-quality relationship, so business customers will become loyal after they receive a price-positive positive relationship from a product offer (Ramaseshan et al., 2013). This is proven to be applicable or in other words can also be applied in the context of $\mathrm{C} 2 \mathrm{C}$ e-marketplace.

Consumers offer their trust and loyalty with an implicit understanding that brands will behave in certain ways and provide benefits through consistent product performance and reasonable prices, promotions and distribution programs (Keller, 2013). On the other hand, nowadays everything is instant and saves time. When consumers are interested in something that is seen on television, they will search through mobile devices. When consumers decide to buy something at the store, they research price and quality online. Today's consumers are very social, they communicate and trust each other. In fact, consumers trust their friends and family more than brands or companies. In short, consumers are currently very connected (Kotler et al., 
2017). In this study $81.65 \%$ were women and the majority of them were 20-39 years old. Women are more price sensitive than men (Anic et al., 2014). In this regard, women are also holistic buyers. Women are more likely to consider everything, from functional benefits, emotional benefits, prices, and the like before determining the true value of a product or service. For certain household categories, women consider products value not only for themselves but for families. The segment of women, digital citizens, and youth is not easily impressed. However, when a company is able to give a good impression on these segments, they will become the most loyal supporters of the brand (Kotler et al., 2017).

Another interesting finding is that relationship equity does not directly affect customer loyalty. The results of this study support the findings of Ramaseshan et al., (2013) which revealed that relationship equity does not provide a direct influence on customer loyalty. The study states that managers must be able to consider several initiatives such as annual reward programs covered by media that aim at social recognition, and retention programs. Companies can also form customers clubs for loyal customers to blend together with companies and strengthen relationships between companies and loyal customers. This will encourage commitment based on customer trust, which will lead them to loyalty (Ramaseshan et al., 2013). Rauyruen and Miller, (2007) stated that the quality of relationships consists of four different but interconnected dimensions, one of which is trust. This illustrates that trust is one of the factors forming the quality of relationships. Thus, from a number of descriptions above, it can be concluded that customer loyalty can be increased through trusts that are influenced by relationship equity, not directly.

In a previous study conducted by Ramaseshan et al., (2013) showed that brand equity has no role in influencing trust and customer loyalty. In contrast to those findings, in this study brand equity plays an important role and contributes positively in influencing trust and customer loyalty. Rosenbroijer, (2001) revealed that corporate buyers make rational decisions and, in such environments, brands have a low influence. In fact, brand equity comes from the brand image perceived by customers (Michell et al., 2001). Brand equity is strongly influenced by three things, namely brand awareness, brand attitudes, and customer perceptions related to brand ethics (Keller, 2013). Brand equity is closely related to individual experience related to products that can be transmitted from individual to individual, even from generation to generation, and when it is difficult to evaluate the quality of a product or service before consumption and this is also related to low involvement purchase where it is conducted through simple decision making (Rust et al., 2004, Leone et al., 2006). Keller, (2013) outlines some of the impacts that brand equity can have, such as increasing perceptions of product performance, increasing customer loyalty, effectiveness of marketing communications, and so on.

\section{CONCLUSIONS AND RECOMMENDATIONS}

There is a partial influence of brand equity and value equity on trust constructs and customer loyalty. Meanwhile, relationship equity affects trust, but not customer loyalty. Trust affects customer loyalty.

In the context of $\mathrm{C} 2 \mathrm{C}$ e-marketplaces such as BukaLapak, Tokopedia, and Shopee, companies must focus on rewarding systems. One form of rewarding systems that can be created to increase value equity is through cash back reward programs in the category of groceries. Second, virtual loyalty cards can be one of the loyalty platform programs to improve customer loyalty in the realm of $\mathrm{C} 2 \mathrm{C}$ e-marketplace. Third, virtual communities in each category of $\mathrm{C} 2 \mathrm{C}$ e-marketplace can be a trigger for increasing interaction between customers and interactions between administration of companies and customers and sellers in the category of groceries. 
For further research it is strongly recommended to analyze customer equity in other contexts such as business to government (B2G), consumer to business $(\mathrm{C} 2 \mathrm{~B})$, government to consumer (G2C), and business to business (B2B). In addition, researchers can also conduct research on other categories besides groceries in $\mathrm{C} 2 \mathrm{C}$ e-marketplace. Furthermore, researchers are also advised to use the longitudinal study approach to gain insight, new findings and development from the concept of this research.

\section{REFERENCES}

[1] Anić, I. D. Suncana Piri Rajh, Edo Rajh, (2014) "Antecedents of food-related consumer decision-making styles", British Food Journal, Vol. 116 Issue: 3 pp.431-450.

[2] Aravindakshan, A., Rust, R. T., Lemon, K. N., dan Zeithaml, V. A. (2004). "Customer equity: Making marketing strategy financially accountable". Journal of Systems Science and Systems Engineering, 13, 405-422.

[3] Ballester, E. and Aleman, J.L. (2001), "Brand trust in the context of consumer loyalty", European Journal of Marketing, Vol. 12 No. 12, pp. 1238-58.

[4] Bolton, R.N., Lemon, K.N. and Verhoef, P.C. (2004), "The theoretical underpinnings of customer asset management: a framework and propositions for future research", Journal of the Academy of Marketing Science, Vol. 32 No. 3, pp. 271-92.

[5] Dan, C. (2014), "Consumer-to-consumer (C2C) electronic commerce: the recent picture", International Journal of Networks and Communications, Vol. 4 No. 2, pp. 29-32.

[6] Delgado-Ballester, E., Munuera-Aleman, J.L. and YagueGuillen, M.J. (2003), "Development and validation of a brand trust scale", International Journal of Market Research, Vol. 45 No. 1, pp. 35-54.

[7] Doney, P.M. and Cannon, J.P. (1997), "An examination of the nature of trust in buyer-seller relationships?” Journal of Marketing, Vol. 61, April, pp. 35-51.

[8] Hogan, J.E., Lemon, K.N. and Rust, R.T. (2002), "Customer equity management: charting new directions for the future of marketing", Journal of Service Research, Vol. 5, August, pp. 4-12.

[9] Johnson, D. and Grayson, K. (2005), "Cognitive and affective trust in service relationships", Journal of Business Research, Vol. 58 No. 4, pp. 500-7.

[10] Johnson, M. D., Herrmann, A., and Huber, F. (2006). "The evolution of loyalty intentions". Journal of Marketing, 70(2), 122-132.

[11] Kim, E. Y. and Brandon, L. (2010). Modeling brand equity for lifestyle brand extension: A strategy approach into Generation Y. vs Baby Boomer. Journal of Global Academy of Marketing Science, 20(1), 35-48.

[12] Leone, R.P., Rao, V.R., Keller, K.L., Luo, A.M., McAlister, L. and Srivastava, R. (2006), "Linking brand equity to customer equity", Journal of Service Research, Vol. 9 No. 2, pp. 125-38.

[13] Meehan, J. and Wright, G.H. (2011), "Power priorities: a buyer-seller comparison of areas of influence", Journal of Purchasing and Supply Management, Vol. 17 No. 1, pp. 32-41.

[14] Jenoba P and Dr. S. Nadarajan, Impact of Service Qualities on Customer Loyalty Towards Commercial Banks in Kanniyakumari District - An Empirical Analysis. Journal of Management, 5(1), 2018, pp. 43-47.

[15] Molinari, L.K., Abratt, R. and Dion, P. (2008), "Satisfaction, quality and value and effects on repurchase and positive word-of-mouth behavioral intentions in a B2B services context", Journal of Services Marketing, Vol. 22 No. 5, pp. 363-73. 
[16] Oliver, R.L. (1999), "Whence consumer loyalty”, Journal of Marketing, Vol. 63, Special Issue, pp. 33-44.

[17] Rachbini, W. (2018). "The Impact of Service Brand Evaluation, Customer Engagement on Brand Trust and Brand Loyalty - Study on Culinary Business as Part of Creative Economy Industry in Indonesia". International Journal of Marketing and Human Resource Management, 9(1), 2018, pp. 01-17.

[18] Rachbini, W. Hatta, I. H. (2018). "E-Lifestyle and Internet Advertising Avoidance”. Jurnal Manajemen, Volume XXII, No. 03, October 2018: 435-448.

[19] Rauyruen, P. and Miller, K.E. (2007), "Relationship quality as a predictor of B2B customer loyalty", Journal of Business Research, Vol. 60 No. 1, pp. 21-31.

[20] Ranaweera, C. and Prabhu, J. (2003), "On the relative importance of customer satisfaction and trust as determinants of customer retention and positive word of mouth", Journal of Targeting, Measurement and Analysis for Marketing, Vol. 12 No. 1, pp. 82-90.

[21] Ramaseshan, B. Fazlul K. Rabbanee, Laine Tan Hsin Hui, (2013) "Effects of customer equity drivers on customer loyalty in B2B context", Journal of Business dan Industrial Marketing, Vol. 28 Issue: 4, pp.335-346.

[22] Khusnul Fikriyah, Ahmad Ajib Ridlwan and Sri Abidah Suryaningsih, Islamic Work Ethics in Zakat Institution in Indonesia: How does it Affect Customer Loyalty?, International Journal of Civil Engineering and Technology (IJCIET) 10(2), 2019, pp. 375-381.

[23] Rosenbroijer, C.J. (2001), "Industrial brand management: a distributor's perspective in the UK fine-paper industry", Journal of Product and Brand Management, Vol. 10 No. 1, pp. 725 .

[24] Romaniuk, J. and Bogomolova, S. (2005), "Variation in brand trust scores", Journal of Targeting, Measurement and Analysis for Marketing, Vol. 13 No. 4, pp. 363-73.

[25] Rust, R.T., Lemon, K.N. and Zeithaml, V.A. (2004), "Return on marketing: using customer equity to focus marketing strategy", Journal of Marketing, Vol. 68, January, pp. 109-27.

[26] Ryssel, R., Ritter, T. and Gemünden, H.G. (2004), “The impact of information technology deployment on trust, commitment and value creation in business relationships", Journal of Business and Industrial Marketing, Vol. 19 No. 3, pp. 197-207.

[27] Singh, J. and Sirdeshmukh, D. (2000), "Agency and trust mechanisms in consumer satisfaction and loyalty judgments", Journal of the Academy of Marketing Science, Vol. 28 No. 1, pp. 150-67.

[28] Sirdeshmukh, D., Singh, J. and Sabol, B. (2002), "Consumer trust, value, and loyalty in relational exchanges", Journal of Marketing, Vol. 66, January, pp. 15-37.

[29] Verhoef, P.C., Langerak, F. and Donkers, B. (2007), "Understanding brand and dealer retention in the new car market: the moderating role of brand tier", Journal of Retailing, Vol. 83 No. 1, pp. 97-113.

[30] Vogel, V., Evanschitzky, H. and Ramaseshan, B. (2008), "Customer equity drivers and future sales", Journal of Marketing, Vol. 72, November, pp. 98-108.

[31] Zeithaml, V.A., Berry, L.L. and Parasuraman, A. (1996), "The behavioral consequences of service quality", Journal of Marketing, Vol. 60 No. 2, pp. 31-46.

[32] Zhang, Hao dan Ko, Eunju dan Kim, Kyung Hoon. (2010). "The Influences of Customer Equity Drivers on Customer Equity and Loyalty in the Sports Shoe Industry: Comparing Korea and China". Journal of Global Fashion Marketing. 1. 110-118.

[33] Blattberg, R.C., Getz, G. and Thomas, J.S. (2001), "Customer Equity: Building and Managing Relationships as Valuable Assets", Harvard Business School Press, Boston, MA. 
[34] Chang, M.K., Cheung, W. and Tang, M. (2013), "Building trust online: interactions among trust building mechanisms", Information dan Management, Vol. 50 No. 7, pp. 439-445.

[35] Enzmann, M., dan Schneider, M. (2005). "Improving Customer Retention in E-commerce through a Secure and Privacy Enhanced Loyalty System”. Information Systems Frontiers, 7(4-5), 359-370.

[36] Funnisia Lamalewa and Elisabeth Lia Riani Kore, the Effect of Teller Service Quality and Satisfaction on Customer Loyalty of Pt Bank Mandiri Tbk Merauke Branch, International Journal of Mechanical Engineering and Technology, 9(12), 2018, pp. 198-204.

[37] Gefen, D., Karahanna, E. and Straub, D.W. (2003), "Trust and TAM in online shopping: an integrated model”, MIS Quarterly, Vol. 27 No. 1, pp. 51-90.

[38] Lemon, K.N., Rust, R.T. and Zeithaml, V.A. (2001), "What drives customer equity?", Marketing Management, Vol. 10 No. 1, pp. 20-5.

[39] Ludin, I. H. B.H., dan Cheng, B. L. (2014). "Factors Influencing Customer Satisfaction and E-Loyalty: Online Shopping Environment among the Young Adults". Management Dynamics in the Knowledge Economy, 2(3), 462-471.

[40] Michell, P., King, J. and Reast, J. (2001), "Brand values related to industrial products", Industrial Marketing Management, Vol. 30 No. 5, pp. 415-25.

[41] Pae, J.H., Samiee, S. and Tai, S. (2002), "Global advertising strategy: the moderating role of brand familiarity and execution style", International Marketing Review, Vol. 19 No. 2, pp. 176-89.

[42] Rust, R.T., Zeithaml, V.A. and Lemon, K.N. (2000). "Driving Customer Equity: How Customer Lifetime Value Is Reshaping Corporate Strategy", The Free Press, New York, NY.

[43] Tabaku, E. Zerellari, M. (2015). "Brand loyalty and loyalty programs; a literature review". Romanian Economic and Business Review, 10(2), 87-102.

[44] Wei, K. Yuzhu Li, Yong Zha, Jing Ma, (2018) "Trust, risk and transaction intention in consumer-to-consumer e-marketplaces: An empirical comparison between buyers' and sellers' perspectives", Industrial Management dan Data Systems.

[45] Villanueva, J. (2003). "Acquisition Channels and Price Discrimination in a Customer Equity Framework". Dissertation, University of California at Los Angeles. 